Servicio de publicaciones y difusión científica (SPDC), Universidad de Las Palmas de Gran Canaria, Parque CientíficoTecnológico, Edificio Polivalente II, C/ Practicante Ignacio Rodríguez, s/n Campus Universitario de Tafira 35017 - Las Palmas de Gran Canaria, Spain.

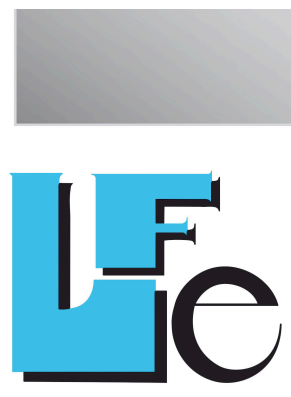

Revista de Lenguas para Fines Específicos

\section{Revista de lenguas para fines específicos}

\author{
elSSN: 2340-8561
}

Journal information, indexing and abstracting details, archives, and instructions for submissions:

https://ojsspdc.ulpgc.es/ojs/index.php/LFE/index

\section{Affective Variables in Second \\ Language Acquisition and their Effect on the Spanish Academic Context}

Alba Muñoz - José Luis Ortega-Martín

Universidad de Granada, Departamento de Didáctica de la Lengua y la Literatura. Facultad de Ciencias de la Educación. Campus Universitario de Cartuja 18011 Granada (Spain).

Article first published online: 27 July 2015.

Article published online with DOI added: 5 April 2016

Revista de Lenguas para fines específicos is licensed under a Creative Commons ReconocimientoNoComercial-SinObraDerivada 4.0 Internacional License. 


\title{
Affective Variables in Second Language Acquisition and their Effect on the Spanish Academic Context
}

\author{
Alba Muñoz \\ Universidad de Granada \\ José Luis Ortega-Martín ${ }^{1}$ \\ Universidad de Granada
}

\begin{abstract}
For many students, learning a Second Language (SL) can either be a rewarding or a threatening experience. Recent studies claim that this is caused by the role that the affective domain plays in the learning process. Since the affective variables are considered the least understood by researchers in Second Language Acquisition (SLA), this paper focuses on them. The main purpose in this research is to study the connection among anxiety, attitude and motivation and their effect on the academic performance of sixty-six Spanish students who are learning English as a SL. Teachers are also observed to know to what extent they alter those students' attitudes, feelings of anxiety and motivation towards their language classes. Since the students who take part in this research share the same teacher, other two teachers are observed in order to analyze whether they have the same effect on their students or not. Results point out that there are clear contrasts between bilingual and non bilingual students and the different performances of the three teachers who were observed.
\end{abstract}

Keywords: Second language acquisition, affect, anxiety, learning

\section{Resumen}

Aprender una segunda lengua puede ser una experiencia enriquecedora o amenazante para muchos estudiantes. Estudios recientes demuestran que esto se debe al papel que la afectividad juega en el proceso de aprendizaje. En la adquisición de una segunda lengua las variables afectivas son las menos estudiadas, por eso este estudio se centra en ellas. El

1 Corresponding author - Universidad de Granada, Departamento de Didáctica de la Lengua y la Literatura. Facultad de Ciencias de la Educación. Campus Universitario de Cartuja 18011 Granada (Spain).

Email: joseluisortegamartin@gmail.es 
principal objetivo de esta investigación es estudiar la conexión que existe entre ansiedad, actitud y motivación y su efecto en el rendimiento académico de sesenta y seis alumnos españoles que estudian inglés como segunda lengua. Los docentes son también observados para analizar hasta qué punto alteran las actitudes, el grado de ansiedad y la motivación de esos alumnos en sus clases de inglés. Ya que los estudiantes que participan en este estudio comparten el mismo profesor, otros dos profesores son observados para analizar si tienen el mismo efecto en sus estudiantes o no. Los resultados señalan que hay claras diferencias entre alumnos bilingües y no bilingües y las actuaciones de los tres docentes analizados.

Palabras clave: Adquisición de una segunda lengua, afectividad, ansiedad, aprendizaje

\section{Introduction}

In the words of Stevick (1980) success in language learning depends more on what goes on inside and between the learners and less on materials, strategies or techniques. The inside comprises the individual factors such as self-esteem, anxiety, attitudes and motivation. Although there are other authors such as Dörnyei (2006), who classify these individual factors into different categories: personality, aptitude, motivation, learning style and strategies. The between is about the relationships or interactions between student-student and teacher-student. Marcos-Llinàs (2007) points out that depending on the personal factors, there are different ways of acting when learning. Language aptitude is the primary source of individual differences in language achievement (Sparks \& Ganschow, 1993). According to Dörnyei \& Skehan (2003), aptitude has been isolated from the process of foreign language learning for many years. Aptitude has to be a central aspect to be taken into account when acquiring a SL. Ellis (2004) states that aptitude and motivation are the most important individual factors. Many people claim to suffer a mental block when learning a second language, although they are good learners in other situations (Horwitz, Horwitz and Cope, 1986). There are students who feel motivated to learn a language, but high levels of anxiety make this process of learning very difficult to cope with. It specially happens when students do not have the mastery of the language.

As it can be seen, the relationship between learning and affect for non-native speakers is essential. So it is clear that what prevents them to perform in the second language classroom is the feeling of anxiety. Psychologists define anxiety as the subjective feeling of tension, apprehension, nervousness and worry. Tsui (1996) remarks that these learners feel more vulnerable to criticism and negative evaluation than in other subjects because in the 
language classes there are more chances to make mistakes than in the rest of subjects.

\section{The concept of affect}

In the fifth century, St. Augustine wrote about how unpleasant was for him to study Greek as a second language by force. He affirmed that fear and pressure did not lead to successful learning, but curiosity and interest.

Jane Arnold (2009) defines the term affect as the area of emotions, feelings, beliefs, moods and attitudes that influence students' behaviour. The affective factors are paramount to take into account when learning or teaching a second language. According to Zheng (2008) "these variables do not operate independently of one another". There are some authors, like Scovel (2000), who claim that emotions might be the factor that most influences language learning. There is a clear relationship between affect and cognition, since affect influences on how people think. Traditionally, the affective domain was not considered in the process of acquiring a second language. Rubio (2004) says that there are different reasons to explain it. The first cause is the lack of awareness about the affective field and its effects on students. The second reason is the lack of techniques, learning tools or methodologies to reduce or prevent anxiety. Nowadays, current literature emphasizes the need to consider these two fields together, reason and emotion cannot be independent. As consequence, if learners feel good, they create a positive environment for learning and their brain would be in the optimal state for acquiring the second language. Stern (1983) comments "the affective component contributes at least as much and often more to language learning than the cognitive skills". In other words, attention to affect makes the process of teaching more effective. Arnold \& Brown (2000) point out that the process of learning a second language has more solid bases when cognition and emotion are considered at the same time.

The current focus on the affective field means an important change in the learning process since the learner is the main and key element.

\section{Anxiety in second language acquisition}

García (2011) defines anxiety as the fear which learners suffer when using the second language. Language anxiety is one of the most important factors which influences the success in the process of language learning (Horwitz, 2001). According to Zheng (2008) the number of anxious language learners is 
astonishing. The more formal a situation is, the more anxiety students feel (Rubio, 2002b). Speaking is the skill which most produces anxiety on learners, since it tends to be one of the most formal situations. Beginners feel more anxiety than those students who have a higher proficiency level of the language. In theory, the more they learn, the less anxiety they feel (García, 2011). But this does not mean that students with high English proficiency have little or no anxiety. Zheng (2008) claims that introverts, who prefer individual work more than working in groups, tend to be more anxious than outgoing students.

Horwitz et al. (1986) say "teachers and students generally feel strongly that anxiety is a major obstacle to be overcome in learning to speak another language" Anxiety is closely related to attitudes and motivation (Zheng, 2008). If these first experiences with the SL make the student get nervous and ashamed when making mistakes, anxiety arises. Rubio (2002a) emphasizes that anxiety develops from negative and repeated experiences in the Foreign Language (FL). Anxiety contributes to students' poor linguistic performances in their SL (Horwitz, 2001).

According to Zheng (2008), there are some manifestations which tell us that learners are suffering from anxiety, such as reluctance to participate, negative attitude and avoidance of work. Participation is essential to language acquisition and students are required to perform in a language that they do not still master. As Horwitz et al. (1986) affirm "any performance in the second language is likely to challenge and individual's self-concept as a competent communicator and lead to reticence, self-consciousness, fear or even panic" (p. 128).

\section{The role of teachers}

The main function of language is communication and if teachers want their students to use this second language without any problem, it is necessary to take into account the affective domain. Learners have to be willing to use the language which they are studying without anxiety. Consequently, new attitudes are required because they can lead to a significant change.

García (2011) says that the teacher has the power to alter students' attitude towards the acquisition of the $\mathrm{SL}$, since he is the main source of motivation for them. Teachers must make an effort to include humanistic or affective activities in their classes. These kinds of activities can be considered as complementary exercises of what they are teaching in a specific moment. 
Paying attention to students, giving confirmation to what they do, transmitting feelings of confidence, smiling or showing interest are some examples of all those things teachers can do in class and a great effort is not required. These things are very simple to perform and they have a high positive impact on learners' behaviour towards their second language.

According to Young (1999), we can find specific activities or techniques for each skill with the purpose of reducing anxiety:

a) Writing: Brainstorming, free writing, outlining, clustering and branching.

b) Listening: visual clues, guessing from context.

c) Speaking: conversation gambits, interviews, role plays, information gaps.

d) Reading: listing, debates, summarizes, group or peer work.

Education has a crucial role on society and attention to affect can bring both effective language learning and a good education to the future, the students, in a relaxed environment.

\section{Study Objectives}

The process of acquiring a second language is influenced by different variables which mostly have negative effects on learners. The following objectives have been selected to study this situation in the Spanish academic context and in order to observe the role of teachers and students.

1. To know if anxiety and the context of the students play a paramount role in the acquisition of the foreign language.

2. To observe teachers' attitudes and interventions during three sessions.

3. To create proposals for improvement and to offer tools for teachers in order to avoid anxiety in the class.

\section{Method}

Participants

The data of this study have been collected with the purpose of observing and analyzing what is happening in the Spanish academic context.

A total of 66 Spanish students take part in this study research. They all study English as a second language in two high schools in Granada (Spain). There 
are 32 males (48\%) and 34 females (52\%) and their ages range from 12 to 19 years old. Regarding their proficiency level in English, 40 students (61\%) are in the first year of Compulsory Secondary Education and twenty-six students (39\%) are studying the second year of Upper Secondary Education.

These students have been divided into three different groups according to their year and stage of education:

\begin{tabular}{llll}
\hline & Group & $\begin{array}{l}\text { Number of } \\
\text { students }\end{array}$ & \% of the total \\
\hline $\begin{array}{l}\text { Compulsory } \\
\begin{array}{l}\text { Secondary } \\
\text { Education }\end{array}\end{array}$ & $\begin{array}{l}\text { Group 1 } \\
\left(1^{\circ} \text { ESO bilingual }\right)\end{array}$ & 20 students & $30 \%$ \\
\cline { 2 - 4 } & $\begin{array}{l}\text { Group 2 } \\
\left(1^{\circ} \text { ESO non }\right. \\
\text { bilingual })\end{array}$ & 20 students & $30 \%$ \\
\hline $\begin{array}{l}\text { Upper Secondary } \\
\text { Education }\end{array}$ & $\begin{array}{l}\text { Group 3 } \\
\left(2^{\circ} \text { Bachiller }\right)\end{array}$ & 26 students & $40 \%$ \\
\hline
\end{tabular}

Table 1. Distribution of students.

It is important to offer a brief description of the three groups:

- The first group is composed of 20 students, $85 \%$ are females and $15 \%$ are males. The average age is 12.36 .

- The second group consists of 20 students and in relation to the gender, $25 \%$ are females and $75 \%$ are males. The average age is 12.94 .

- The third group is made of 26 students and according to their gender, $46 \%$ are females and $54 \%$ are males. The average age is 17.5 years old.

It is also important to say that the first and the second group do share the same teacher. The difference relies on the fact that the first set of students belongs to the bilingual program and their behaviour is really good. In contrast, the same cannot be said in relation to the non bilingual group, since they are all the time talking to each other and showing a bad attitude. Their average age is very high (12.94), so there are many students who have studied the same level twice.

Three different teachers are observed in order to analyze how similar or different their ways of acting or interventions are. All these teachers teach English as a second language at different stages: ESO and Bachillerato, although the three classes observed here only belong to Compulsory Secondary Education. The teacher in session 2 has been teaching for more than thirty years and the other two teachers are much younger. 
A context of the three different sections that were observed is provided here:

- Session 1: The teaching level observed is the last year of the second stage of Compulsory Secondary Education $\left(4^{\circ} \mathrm{ESO}\right)$. The group belongs to the bilingual program and there are just 11 students in the class.

- Session 2: The teaching level is the first year of the first stage of Compulsory Secondary Education ( $1^{\circ} \mathrm{ESO}$ ). It is a bilingual group and 23 students attend this class. These students are the same learners who completed the questionnaire of this research.

- Session 3: The teaching level is the first year of the second stage of Compulsory Secondary Education and there are 16 students in this non bilingual class.

\section{Instruments and Procedure}

A questionnaire was administered to all participants during class time and a table of observation was taken into consideration to observe the attitude of three different teachers.

The questionnaire: Taking into account some variables from the "Foreign Language Classroom Anxiety Scale, FLCAS" from Horwitz et al. (1986), a questionnaire has been designed to collect the data focusing on the affective variables (see Appendix A). This questionnaire has been distributed among students with different levels of English, so the sample is heterogeneous. It is written in Spanish to make items easier to understand and avoid possible problems related to comprehension. Respondents are required to respond anonymously, by doing so "subjects tend to share information of a sensitive nature more easily" (Ortega-Martín \& Villoria, 2004). The questionnaire has two parts:

- Fifteen background questions (variables 1-15), including age and gender, some of them are open-ended. This part provides the context of these students.

- The Likert scale (variables 16-34), which is based on a rating scale from 1 (I strongly disagree) to 5 (I strongly agree), as Arnaiz \& Guillén (2013) suggest. This second part is composed by 19 items which provide all the information related to attitude, anxiety and motivation.

The items presented in this questionnaire (see Appendix A) are reflective of test-anxiety, fear of negative evaluation, attitude and motivation. The distribution of the questionnaire allows working on quantitative and qualitative data. It was also ensured that all the questionnaires were completely filled out, so all the questions were answered. 
A table of observation: It has been designed to measure teachers' attitudes and behaviours during their classes. Three different teachers have been observed, so clear contrasts among their ways of teaching can be analyzed and how they affect to the students' affective domains.

Analysis of the Data

All the data were carefully collected and introduced in an Excel spreadsheet. This task was reviewed independently by the two authors of this research, in order to ensure that no errors were introduced during the whole process. Due to the nature of the data, on the one hand, to summarize the results of variables 1-15 and the observation of teachers, percentages corresponding to each possible answer were calculated automatically. To find relationships, we have calculated the correlations for each pair of variables 1-15. We have filtered those pairs with a value below 0.4 and over 0.4 . Although we evaluate pairs with a medium correlation level, it allows us to observe certain patterns. On the other hand, average scores were computed to summarize results in variables 16-34. The average values of variables grouped by anxiety, attitude and motivation were also calculated to study the similarities and contrasts between the three groups of students.

\section{Results}

This section will show the findings obtained in this research and it will be divided into two parts: results based on the questionnaire and results based on the observation of teachers.

Results based on the questionnaire

The following table shows the results obtained from the analysis of variables 1-15:

\begin{tabular}{llll}
\hline Variables & Group 1 (bilingual) & $\begin{array}{l}\text { Group 2 } \\
\text { (non bilingual) }\end{array}$ & Group 3 \\
\hline 1. Do you like English? & Yes 100\% & Yes 80\% & Yes 81\% \\
& & No 20\% & No 19\% \\
\hline 2. Your interest in the subject is & Low 0\% & Low 15\% & Low 15\% \\
& Medium 30\% & Medium 45\% & Medium 50\% \\
& High 70\% & High 40\% & High 35\% \\
\hline $\begin{array}{l}\text { 3. Would you change anything } \\
\text { related to the subject? }\end{array}$ & $*$ & & \\
\hline
\end{tabular}




\begin{tabular}{|c|c|c|c|}
\hline $\begin{array}{l}\text { 4. How do you consider yourself in } \\
\text { English? }\end{array}$ & $\begin{array}{l}\text { Good 55\% } \\
\text { Ordinary } 45 \%\end{array}$ & $\begin{array}{l}\text { Good } 25 \% \\
\text { Ordinary } 50 \% \\
\text { Bad } 25 \%\end{array}$ & $\begin{array}{l}\text { Good } 15 \% \\
\text { Ordinary } 65 \% \\
\text { Bad } 5 \%\end{array}$ \\
\hline 5. Have you ever repeated a grade? & $\begin{array}{l}\text { Yes } 0 \% \\
\text { No } 100 \%\end{array}$ & $\begin{array}{l}\text { Yes } 65 \% \\
\text { No } 35 \%\end{array}$ & $\begin{array}{l}\text { Yes } 15 \% \\
\text { No } 85 \%\end{array}$ \\
\hline $\begin{array}{l}\text { 6. Which mark did you have last } \\
\text { term? }\end{array}$ & Average score 7.95 & $\begin{array}{l}\text { Average score } \\
4.95\end{array}$ & Average score 6.38 \\
\hline 7. Your parents can speak English: & $\begin{array}{l}\text { Nothing } 40 \% \\
\text { A little bit 55\% } \\
\text { Very much 5\% } \\
\end{array}$ & $\begin{array}{l}\text { Nothing } 15 \% \\
\text { A little bit } 70 \% \\
\text { Very much } 15 \%\end{array}$ & $\begin{array}{l}\text { Nothing } 42 \% \\
\text { A little bit } 46 \% \\
\text { Very much } 12 \%\end{array}$ \\
\hline 8. Do you use English at home? & $\begin{array}{l}\text { Yes 5\% } \\
\text { No } 95 \% \\
\text { Sometimes 0\% }\end{array}$ & $\begin{array}{l}\text { Yes 5\% } \\
\text { No } 90 \% \\
\text { Sometimes 5\% }\end{array}$ & $\begin{array}{l}\text { Yes } 4 \% \\
\text { No } 96 \% \\
\text { Sometimes 0\% }\end{array}$ \\
\hline 9. Do you have private classes? & $\begin{array}{l}\text { Yes } 5 \% \\
\text { No } 95 \%\end{array}$ & $\begin{array}{l}\text { Yes } 15 \% \\
\text { No } 85 \%\end{array}$ & $\begin{array}{l}\text { Yes } 19 \% \\
\text { No } 81 \%\end{array}$ \\
\hline $\begin{array}{l}\text { 10. Do you watch movies or TV } \\
\text { series in English? }\end{array}$ & $\begin{array}{l}\text { Yes } 35 \% \\
\text { No } 65 \%\end{array}$ & $\begin{array}{l}\text { Yes } 45 \% \\
\text { No } 55 \%\end{array}$ & $\begin{array}{l}\text { Yes } 46 \% \\
\text { No } 54 \%\end{array}$ \\
\hline $\begin{array}{l}\text { 11. Have you ever been abroad in } \\
\text { summer? }\end{array}$ & $\begin{array}{l}\text { Yes } 0 \% \\
\text { No } 100 \%\end{array}$ & $\begin{array}{l}\text { Yes } 0 \% \\
\text { No } 100 \%\end{array}$ & $\begin{array}{l}\text { Yes } 27 \% \\
\text { No } 73 \%\end{array}$ \\
\hline $\begin{array}{l}\text { 12. Which advice would you give to } \\
\text { future teachers? }\end{array}$ & * & & \\
\hline $\begin{array}{l}\text { 13. Do you think that teachers } \\
\text { pressure students in order to get } \\
\text { an immediate answer? }\end{array}$ & $\begin{array}{l}\text { Yes } 10 \% \\
\text { No } 90 \%\end{array}$ & $\begin{array}{l}\text { Yes } 40 \% \\
\text { No } 60 \%\end{array}$ & $\begin{array}{l}\text { Yes } 54 \% \\
\text { No } 46 \%\end{array}$ \\
\hline $\begin{array}{l}\text { 14. Do you have enough time to } \\
\text { give an answer? }\end{array}$ & * & & \\
\hline $\begin{array}{l}\text { 15. Do you think that there is a lack } \\
\text { of respect towards teachers? }\end{array}$ & $\begin{array}{l}\text { Yes } 20 \% \\
\text { No } 30 \% \\
\text { Some of them } 50 \%\end{array}$ & $\begin{array}{l}\text { Yes } 70 \% \\
\text { No } 20 \% \\
\text { Some of them } 5 \%\end{array}$ & $\begin{array}{l}\text { Yes } 50 \% \\
\text { No } 46 \% \\
\text { Some of them } 4 \%\end{array}$ \\
\hline
\end{tabular}

Table 2. Results from the three groups, variables 1-15 from the questionnaire. Note: Variables marked with an * are open questions and results are not included.

Table 3 shows the results obtained from the analysis of variables 16-34:

\begin{tabular}{|c|c|c|c|}
\hline VARIABLES & GROUP 1 & GROUP 2 & GROUP 3 \\
\hline 16. I feel confident when speaking in English. & 3.65 & 2.85 & 3.12 \\
\hline $\begin{array}{l}\text { 17. I do not worry about making mistakes in } \\
\text { front of my classmates. }\end{array}$ & 3.45 & 3.65 & 3.73 \\
\hline $\begin{array}{l}\text { 18. I get nervous when the teacher asks } \\
\text { questions in class. }\end{array}$ & 2.35 & 2.45 & 2.56 \\
\hline $\begin{array}{l}\text { 19. During the class, I find myself thinking } \\
\text { about things that have nothing to do with the } \\
\text { subject. }\end{array}$ & 2.25 & 3.35 & 3.58 \\
\hline $\begin{array}{l}\text { 20. It embarrasses me to speak in English in } \\
\text { front of my classmates. }\end{array}$ & 2.20 & 2.60 & 2.12 \\
\hline 21. I worry about failing this subject. & 4.10 & 4.55 & 4.08 \\
\hline
\end{tabular}




\begin{tabular}{|c|c|c|c|}
\hline $\begin{array}{l}\text { 22. In my English class, I get so nervous that I } \\
\text { forget things I know. }\end{array}$ & 2.10 & 2.85 & 2.85 \\
\hline $\begin{array}{l}\text { 23. I do not understand why some people get } \\
\text { so nervous when they have to participate in } \\
\text { class. }\end{array}$ & 2.85 & 3.10 & 2.46 \\
\hline 24. It embarrasses me to volunteer answers. & 2.80 & 2.25 & 2.54 \\
\hline $\begin{array}{l}\text { 25. I would feel uncomfortable or nervous if I } \\
\text { spoke with native speakers. }\end{array}$ & 3.60 & 2.70 & 2.81 \\
\hline $\begin{array}{l}\text { 26. Even if I am well prepared for the class, I } \\
\text { feel anxious about it. }\end{array}$ & 1.80 & 2.50 & 2.54 \\
\hline $\begin{array}{l}\text { 27. I do not like that my teacher is ready to } \\
\text { correct every mistake I make. }\end{array}$ & 2.00 & 2,05 & 2.38 \\
\hline $\begin{array}{l}28 . \text { I sit in the last row to avoid be named by my } \\
\text { language teacher. }\end{array}$ & 1.30 & 1.90 & 1.77 \\
\hline $\begin{array}{l}\text { 29. I think that my classmates are better at } \\
\text { English than me. }\end{array}$ & 2.75 & 3.15 & 3.04 \\
\hline $\begin{array}{l}\text { 30. In my English class, I feel more tense and } \\
\text { nervous than in the rest of subjects. }\end{array}$ & 1.35 & 1.85 & 2.19 \\
\hline $\begin{array}{l}\text { 31. When I speak in English, I am afraid that } \\
\text { the other students laugh at me. }\end{array}$ & 2.55 & 3.15 & 1.96 \\
\hline 32. I would love to take more English classes. & 3.95 & 3.30 & 2.92 \\
\hline $\begin{array}{l}\text { 33. There are some students "who always } \\
\text { participate in class". }\end{array}$ & 4.10 & 3.60 & 3.88 \\
\hline $\begin{array}{l}\text { 34. I will not be able to learn how to speak } \\
\text { English. }\end{array}$ & 1.40 & 2.65 & 1.69 \\
\hline
\end{tabular}

Table 3. Average values of the variables in The Likert Scale, variables 16-34.

Table 4 includes the results of variables 16-34:

\begin{tabular}{llll}
\hline & Group 1 & Group 2 & Group 3 \\
\cline { 2 - 3 } Anxiety $(\mathrm{v} .16-18,20,22-28,30,31,33)$ & 2.23 & 2.38 & 2.38 \\
\hline & & & \\
Attitude and motivation (v. 19, 21, 29, 32) & 3.33 & 2.74 & 2.54 \\
\hline $\begin{array}{l}\text { Table 4. Average scores of The Likert Scale, variables 16-34. Note: Scales of variables 16, 17, 19, 23, } 29 \text { and } \\
\text { 34 have been reversed in order to show a positive correlation with the affective factors. }\end{array}$
\end{tabular}

Results based on the observation of teachers

Table 5 shows the results obtained from the observation of the teachers: 


\begin{tabular}{|c|c|c|c|}
\hline ITEMS & Session \#1 & Session \#2 & Session \#3 \\
\hline 1. The teacher gives time to interact. & $100 \%$ & $75 \%$ & $90 \%$ \\
\hline 2. The teacher interrupts students when they talk. & $0 \%$ & $8 \%$ & $0 \%$ \\
\hline 3. The teacher always asks the best students. & \multirow{2}{*}{ * } & \multirow{2}{*}{ * } & \multirow{2}{*}{ * } \\
\hline 4. The teacher asks those students who need help. & & & \\
\hline $\begin{array}{l}\text { 5. The teacher creates an appropriate environment, } \\
\text { establishing good relationships. }\end{array}$ & $100 \%$ & $33 \%$ & $90 \%$ \\
\hline $\begin{array}{l}\text { 6. The teacher gives confirmation to what students say, } \\
\text { transmitting feelings of confidence. }\end{array}$ & $100 \%$ & $57 \%$ & $82 \%$ \\
\hline $\begin{array}{l}\text { 7. The teacher accepts a variety of answers, there is not } \\
\text { only a correct answer. }\end{array}$ & $100 \%$ & $38 \%$ & $100 \%$ \\
\hline 8. The teacher avoids over-correcting students' mistakes. & $100 \%$ & $100 \%$ & $100 \%$ \\
\hline
\end{tabular}

Table 5. Observation of teachers and results. Note: * In sessions 1 and 3 the teachers do not make any distinction between high or low achievers. They place emphasis on those students who need help. In session 2 , the teacher only asks best students in order to get a correct and immediate answer.

In order to calculate the correlations between pairs of variables, answers were mapped to values. According to gender, male was considered as 0 and female as 1 . Non-bilingual students were considered as 0 , in contrast to bilingual students to bilingual students who were considered as 1 . Finally, yes/no questions were mapped to $1 / 0$, respectively. For those variables with an intermediate option, that option was considered as 0.5 .

Table 6 includes the correlations for group 1:

\begin{tabular}{|c|c|c|c|c|c|c|c|c|c|c|c|c|c|c|}
\hline & A & $\mathrm{G}$ & $\mathrm{V} 1$ & V2 & V4 & V5 & V6 & V7 & V8 & V9 & V10 & V11 & V13 & V15 \\
\hline$A$ & 1.00 & -0.28 & - & 0.02 & 0.24 & - & 0.18 & -0.47 & -0.17 & 0.31 & -0.10 & - & -0.17 & 0.10 \\
\hline G & & 1.00 & - & 0.03 & -0.10 & - & -0.12 & 0.48 & 0.10 & 0.10 & -0.28 & - & 0.10 & -0.26 \\
\hline V1 & & & - & 0.00 & 0.00 & - & 0.00 & 0.00 & 0.00 & 0.00 & 0.00 & - & 0.00 & 0.00 \\
\hline V2 & & & & 1.00 & 0.07 & - & 0.55 & -0.21 & -0.35 & -0.35 & 0.02 & - & -0.35 & 0.37 \\
\hline V4 & & & & & 1.00 & - & 0.76 & 0.15 & 0.21 & -0.25 & 0.24 & - & 0.21 & 0.30 \\
\hline V5 & & & & & & - & 0.00 & 0.00 & 0.00 & 0.00 & 0.00 & - & 0.00 & 0.00 \\
\hline V6 & & & & & & & 1.00 & -0.07 & -0.19 & -0.39 & 0.09 & - & 0.00 & 0.30 \\
\hline V6 & & & & & & & & 1.00 & 0.54 & -0.26 & 0.08 & - & 0.14 & -0.21 \\
\hline V8 & & & & & & & & & 1.00 & -0.05 & 0.31 & - & -0.05 & -0.29 \\
\hline V9 & & & & & & & & & & 1.00 & -0.17 & - & -0.05 & -0.29 \\
\hline V10 & & & & & & & & & & & 1.00 & - & -0.17 & -0.04 \\
\hline V11 & & & & & & & & & & & & - & 0.00 & 0.00 \\
\hline V13 & & & & & & & & & & & & & 1.00 & 0.03 \\
\hline V15 & & & & & & & & & & & & & & 1.00 \\
\hline
\end{tabular}

Table 6. Correlations for Group 1 ( $A=$ age; G=gender). 
Table 7 includes the correlations for Group 2:

\begin{tabular}{|c|c|c|c|c|c|c|c|c|c|c|c|c|c|c|}
\hline & A & G & V1 & V2 & V4 & V5 & V6 & V7 & V8 & V9 & V10 & V11 & V13 & V15 \\
\hline $\bar{A}$ & 1.00 & 0.15 & -0.16 & -0.37 & 0.09 & 0.81 & -0.12 & -0.12 & 0.27 & -0.18 & 0.00 & -0.30 & 0.00 & 0.16 \\
\hline G & & 1.00 & 0.29 & -0.21 & 0.00 & 0.18 & 0.14 & -0.21 & -0.18 & 0.40 & 0.17 & -0.13 & 0.24 & 0.04 \\
\hline V1 & & & 1.00 & 0.54 & 0.35 & -0.10 & 0.31 & 0.00 & 0.16 & 0.21 & 0.20 & 0.11 & -0.10 & 0.19 \\
\hline V2 & & & & 1.00 & 0.51 & -0.19 & 0.22 & 0.13 & 0.34 & 0.05 & 0.11 & 0.25 & -0.44 & 0.02 \\
\hline V4 & & & & & 1.00 & 0.15 & 0.39 & -0.13 & 0.44 & 0.00 & 0.28 & 0.32 & -0.14 & -0.18 \\
\hline V5 & & & & & & 1.00 & -0.26 & -0.19 & 0.23 & 0.01 & 0.03 & -0.31 & -0.04 & 0.11 \\
\hline V6 & & & & & & & 1.00 & 0.17 & 0.39 & -0.17 & 0.12 & 0.28 & 0.06 & 0.19 \\
\hline V6 & & & & & & & & 1.00 & 0.19 & 0.00 & -0.18 & 0.00 & 0.00 & 0.00 \\
\hline V8 & & & & & & & & & 1.00 & -0.13 & -0.28 & -0.07 & -0.26 & 0.18 \\
\hline V9 & & & & & & & & & & 1.00 & 0.18 & -0.10 & 0.23 & -0.46 \\
\hline V10 & & & & & & & & & & & 1.00 & 0.25 & 0.49 & -0.24 \\
\hline V11 & & & & & & & & & & & & 1.00 & 0.28 & -0.44 \\
\hline V13 & & & & & & & & & & & & & 1.00 & -0.56 \\
\hline V15 & & & & & & & & & & & & & & 1.00 \\
\hline
\end{tabular}

Table 7. Correlations for Group 2 ( $A=$ age; $G=$ gender).

Table 8 includes the correlations for group 3:

\begin{tabular}{|c|c|c|c|c|c|c|c|c|c|c|c|c|c|c|}
\hline & $A$ & $\mathrm{G}$ & V1 & V2 & V4 & V5 & V6 & V7 & V8 & V9 & V10 & V11 & V13 & V15 \\
\hline$A$ & 1.00 & -0.10 & -0.07 & -0.34 & -0.04 & 0.71 & 0.03 & 0.23 & 0.40 & -0.07 & 0.10 & 0.29 & 0.21 & 0.05 \\
\hline G & & 1.00 & -0.14 & -0.15 & -0.20 & -0.18 & -0.40 & 0.20 & -0.19 & 0.14 & -0.08 & 0.13 & 0.24 & -0.08 \\
\hline V1 & & & 1.00 & 0.28 & 0.30 & 0.21 & 0.34 & 0.36 & 0.10 & -0.01 & 0.06 & 0.30 & -0.45 & 0.10 \\
\hline V2 & & & & 1.00 & 0.11 & -0.12 & 0.22 & -0.12 & -0.35 & -0.28 & -0.03 & 0.08 & -0.08 & 0.18 \\
\hline V4 & & & & & 1.00 & 0.03 & 0.64 & 0.36 & 0.35 & -0.13 & -0.07 & 0.19 & -0.59 & 0.07 \\
\hline V5 & & & & & & 1.00 & 0.16 & 0.20 & 0.47 & -0.21 & 0.25 & 0.22 & 0.18 & 0.22 \\
\hline V6 & & & & & & & 1.00 & -0.02 & 0.18 & -0.18 & 0.05 & 0.04 & -0.46 & 0.17 \\
\hline V6 & & & & & & & & 1.00 & 0.39 & -0.07 & 0.08 & 0.41 & -0.08 & 0.06 \\
\hline V8 & & & & & & & & & 1.00 & -0.10 & 0.22 & 0.33 & -0.22 & 0.21 \\
\hline V 9 & & & & & & & & & & 1.00 & -0.06 & -0.08 & 0.06 & 0.00 \\
\hline V10 & & & & & & & & & & & 1.00 & 0.31 & -0.07 & 0.08 \\
\hline V11 & & & & & & & & & & & & 1.00 & -0.13 & 0.27 \\
\hline V13 & & & & & & & & & & & & & 1.00 & 0.16 \\
\hline V15 & & & & & & & & & & & & & & 1.00 \\
\hline
\end{tabular}

Table 8. Correlations for Group 3 ( $A=$ age; G=gender).

Table 9 includes the correlations for all groups: 


\begin{tabular}{|c|c|c|c|c|c|c|c|c|c|c|c|c|c|c|c|}
\hline & A & G & V1 & V2 & V4 & V5 & V6 & V7 & V8 & V9 & V10 & V11 & V13 & V15 & Bil. \\
\hline \multirow[t]{2}{*}{ A } & 1.0 & - & - & - & - & 0.03 & - & - & 0.01 & 0.12 & 0.07 & 0.46 & 0.36 & - & -0.59 \\
\hline & 0 & 0.14 & 0.18 & 0.30 & 0.24 & & 0.11 & 0.08 & & & & & & 0.06 & \\
\hline \multirow[t]{2}{*}{ G } & & 1.00 & 0.14 & 0.03 & 0.09 & - & 0.15 & 0.04 & - & 0.12 & - & 0.04 & 0.01 & - & 0.44 \\
\hline & & & & & & 0.26 & & & 0.11 & & 0.09 & & & 0.19 & \\
\hline \multirow[t]{2}{*}{ V1 } & & & 1.00 & 0.42 & 0.36 & - & 0.37 & 0.14 & 0.10 & 0.03 & 0.07 & 0.14 & - & 0.06 & 0.26 \\
\hline & & & & & & 0.07 & & & & & & & 0.36 & & \\
\hline \multirow[t]{2}{*}{ V2 } & & & & 1.00 & 0.36 & - & 0.37 & - & - & - & - & - & - & 0.10 & 0.33 \\
\hline & & & & & & 0.22 & & 0.09 & 0.08 & 0.22 & 0.01 & 0.04 & 0.35 & & \\
\hline \multirow[t]{2}{*}{ V4 } & & & & & 1.00 & - & 0.62 & 0.08 & 0.32 & - & 0.08 & 0.00 & - & - & 0.40 \\
\hline & & & & & & 0.08 & & & & 0.16 & & & 0.41 & 0.04 & \\
\hline \multirow[t]{2}{*}{ V5 } & & & & & & 1.00 & - & 0.16 & 0.26 & - & 0.13 & 0.02 & 0.15 & 0.30 & -0.39 \\
\hline & & & & & & & 0.35 & & & 0.03 & & & & & \\
\hline \multirow[t]{2}{*}{ V6 } & & & & & & & 1.00 & - & 0.11 & - & 0.02 & 0.00 & - & - & 0.52 \\
\hline & & & & & & & & 0.11 & & 0.24 & & & 0.35 & 0.01 & \\
\hline \multirow[t]{2}{*}{ V6 } & & & & & & & & 1.00 & 0.37 & & 0.02 & 0.20 & 0.01 & 0.06 & -0.13 \\
\hline & & & & & & & & & & 0.07 & & & & & \\
\hline \multirow[t]{2}{*}{ V8 } & & & & & & & & & 1.00 & - & 0.07 & 0.14 & - & 0.08 & -0.01 \\
\hline & & & & & & & & & & 0.10 & & & 0.18 & & \\
\hline \multirow[t]{2}{*}{ V9 } & & & & & & & & & & 1.00 & 0.02 & 0.01 & 0.17 & - & -0.17 \\
\hline & & & & & & & & & & & & & & 0.16 & \\
\hline \multirow[t]{2}{*}{ V10 } & & & & & & & & & & & 1.00 & 0.20 & 0.14 & - & -0.10 \\
\hline & & & & & & & & & & & & & & 0.03 & \\
\hline V11 & & & & & & & & & & & & 1.00 & 0.06 & 0.11 & -0.23 \\
\hline \multirow[t]{2}{*}{ V13 } & & & & & & & & & & & & & 1.00 & - & -0.41 \\
\hline & & & & & & & & & & & & & & 0.04 & \\
\hline V15 & & & & & & & & & & & & & & 1.00 & -0.18 \\
\hline Bil. & & & & & & & & & & & & & & & 1.00 \\
\hline
\end{tabular}

Table 9. Correlations for all groups ( $A=$ age; $G=$ gender).

\section{Discussion}

This section will detail the findings of this research by analyzing the questionnaire and the tables of observation. All the variables that are interrelated will be put together to avoid repetitions. The purpose here is to meet with the first and the second objectives formulated in this research.

How the context of the students influences the process of learning a SL

(variables 1-15)

This first section will take into account the first part of the questionnaire (as shown in Table 2). There is only one group in which students declare that they all like English or the subject itself according to variable 1 (v.1). These learners belong to the bilingual program and all of them are highly motivated, $70 \%$ of the learners indeed (v.2). In contrast, having a look at the other two groups, most of these students like English but just 40\% (group 2) 
and 35\% (group 3) are motivated with the subject. It is surprising that all the students from the bilingual group like English and they have a very good motivation towards the subject. A clear contrast can be observed here between the levels of motivation of bilingual and non bilingual students.

When students are asked if they would change anything related to the subject (v.3), the answers are quite varying. Sixty per cent of the bilingual students (group 1) are very happy with the subject and the teacher, so they would not change anything. The rest of their answers are just proposals of extra activities they could perform in class. As commented before, the attitude and behaviour of students in group 2 is not good enough and something surprising about their answers is the fact that they complain about how noisy their classes are. It is very surprising to observe how the same students who are always distracting the rest or speaking up are the same people who complain about the noise. Learners in group 3 are aware of the importance of English in society nowadays and what they want to achieve is to master this SL in an appropriate way. They want to be able to face authentic situations without any linguistic problem. From their answers, it can be observed how these students consider their level as very poor and they want a teacher who motivates them. Taking into account the responses from Group 1 (bilingual), we can clearly observed how comfortable they feel in their lessons and they even give proposals. The same situation does not take place in Group 2 since their answers are mainly complaints. We again can observe differences among bilingual and non bilingual students.

When students are asked how they consider themselves in English (v.4), another clear contrast can be seen among the three groups. While 55\% of students in group 1 consider themselves as good at English, 25\% in group 2 and $15 \%$ in group 3 think they are good at the subject. If these students were highly motivated by the teacher, they would consider themselves as better SL learners and their performance and attitude towards the subject would improve as well. In this research, bilingual students have shown to have more self-confidence than non bilingual learners.

Another remarkable difference can be observed in variable 5, since 65\% of students in group 2 have repeated a grade at least once and there are no students in that situation in the bilingual group. Bearing in mind the average scores of each set of students (v.6), bilingual students have the highest score (7.95) while non bilingual students have the lowest mark (4.95).

When students are asked which advice they would give to future teachers (v.12), several similarities can be found. Students in group 1 want a teacher 
who is tactful, does not shout or gets nervous with them. They also want to take part in important decisions. Group 2 agrees with the previous one that patience should predominate among teachers. Finally, group 3 advices that the ideal teacher has to be patient, comprehensive and respect every student in the same way: "the teacher must not make fun of students who do not pronounce or answer correctly", moreover "English should be used by teacher and students during the whole lesson".

As for the correlations among variables, several aspects need to be discussed. Firstly, we will talk about the different correlations that exist at the level of the three groups.

A positive correlation can be observed between variables 1 and 2 , since the students who like English tend to have a very high interest in the subject. In contrast, those students who do not like the subject show a medium or low interest in it.

In variables 4 and 6 , it is interesting to see how in this study these students consider themselves as good or bad in the subject depending on the mark they get. This connection is also reported by Guillén, Pérez-Luzardo \& Arnaiz (2013). Bilingual students tend to have better marks than no bilingual learners. Therefore, it would be interesting to analyze the possible causes of this situation: if these students are clearly divided into good or bad learners, if the teacher demands more effort to non bilingual students or if it is true that bilingual have a high level of English and that is the reason why they get better marks than non bilinguals.

There is a negative correlation between variables 4 and 13: we observe a tendency to connect the self-esteem of these students and the image they have about the way of teaching of their teacher. This could cause that students consider the subject as a barrier; therefore, teachers could take this fact into account in order to avoid this type of situation. In spite of using a language that is different from their mother tongue, it is significant to see how bilingual students do not think that their teacher pressures them and they tend to feel comfortable.

Some tendencies only take place at the level of each group and they will be detailed now.

In group 1, a clear tendency can be observed in relation to the level of interest in the subject and the marks of these students (variables 2 and 6). In variables 7 and 8 , it is common to observe how those parents who speak English do not use this language with their children at home. 
In group 2, it is interesting to highlight that girls tend to have more private classes than boys (gender and variable 9). Taking into account variables 2 and 13 , these students tend to show more interest when they feel less pressure from their teacher. In variables 10 and 13, we see how those students who feel pressure watch TV series or films and this could be due to the fact that they want to improve their skills in their second language. Another tendency can be observed in variables 13 and 15 since those learners who think that there is a lack of respect towards teachers, also think that teachers do not pressure students to get immediate o correct answers. It would be interesting to study to what extent this situation is true or not.

In group 3, those students whose parents speak English, go abroad more frequently (variables 7 and 11). Taking into account variables 1, 4, 6 and 13, a clear tendency can be observed amongst those students who like English and have a high level of interest and good marks since they tend to think that teachers do not pressure students.

Identifying anxious students (Variables 16-34)

In this next group of variables, those students suffering from anxiety during the process of SL acquisition will be identified. Table 3 contains the average score of the responses of the three groups in the second part of the questionnaire.

In variable 16, students who belong to the bilingual group are the most confident when using their SL (3.65); while students from the non bilingual group are less secure when mastering it (2.85). In spite of the fact that the first group has the highest average in this variable, their confidence should be higher since they are studying in a bilingual program and they have a very good level at English.

Although the average values are quite similar in v.17, the third group has the highest value here (3.73) and the bilingual group the lowest average (3.45). It is surprising that students who are supposed to be very well prepared are afraid of making mistakes in front of others. In variable 18, students from group 1 seem to be the less nervous (2.35) when the teacher asks questions in class while students from group 3 are the most anxious (2.56). Tsui (1996) said that students who had difficulties in expressing in their SL were more vulnerable to criticism or afraid of making mistakes. In contrast to what this researcher claimed, results in the present study have shown how non bilingual students with a very low level at the language (group 2) do not worry 
that much about making mistakes or how they do not get nervous when the teacher asks questions.

The difference is quite significant in variable 19. The first group (2.25) seems to pay more attention in the class than the other two groups (3.35) and (3.58). These data also show how interested and motivated these bilingual students are.

It is also very surprising that students in group 3 feel less embarrassed when speaking in front of their classmates (2.12) than groups 1 and 2. The following group is the bilingual with an average of 2.20.

Although the non bilingual group has the lowest attitude and motivation in this subject, they are the most worried about failing the subject (4.55 in v.20). They ask for quiet lessons, so the teacher can explain the unit.

It is quite interesting how the non bilingual students (3.10) are the only group which agrees more with "I do not understand why some people get so nervous when they have to participate in class" (v. 23). If they agree with this item is because they do not get that nervous when they are named by the teacher with the purpose of speaking in English.

In variable 24, all the groups do not mind to volunteer to read aloud or to do any other activity in class. But it is unexpected to observe how these bilingual students feel more embarrassed (2.80) than the non bilingual learners (2.25). The same happens in v. 25, since the first group would feel uncomfortable or nervous when speaking with native speakers (3.60) and the second group does not seem to worry too much about it (2.70).

Students from the three groups agree that they do like their teacher to correct every mistake they make (v. 27). Any of them sit in the last row to avoid be named by the teacher ( $v$. 28). None of these students feel more tense or nervous in the English class than in the rest of subjects (v.30).

In variable 32 , the bilingual students are the most motivated and interested in the subject (3.95).

There is a general agreement among the three groups in variable 33 . It seems that the same learners participate every time the teacher formulates an answer or they are directly asked. Tsui (1996) stated that teachers do it to make themselves feel good about their teaching. In the present research, this only makes students feel bad or neglected and it reduces their attitude and motivation and increases anxiety on them. 
None of these students think they will not be able to learn English (v. 34). Although the average in group 2 is slightly higher than the other two groups, they keep having a good attitude towards the subject.

Table 4 shows how anxiety is slightly lower in the bilingual group (group 1). Meanwhile, anxiety results are quite similar across the three groups. Concerning attitude and motivation, it can be seen how the bilingual group has a remarkably highest average, while the other two groups are quite similar between them.

We can observe a relation between the degree of anxiety in students (see Table 4) and variables 13 and 15 based on how these students perceive teachers in terms of respect and pressure.

On the one hand, the first group who reports less anxiety than the other two groups states that teachers do not pressure students and almost half of the group thinks that there is a lack of respect towards teachers. On the other hand, groups 2 and 3 report a higher level of anxiety, and this seems to be related to their beliefs that students are pressured by the teacher and that there is a high degree of lack of respect.

The values of anxiety variables (Table 4) in the present study have been compared to those reported in the first FLCAS of Horwitz et al. (1986). Clear contrasts and similarities among these different generations and their evolution in the SL class can be observed. To begin with, there is an interesting difference in variable 17 since students who took part in the original scale claimed to be worried about making mistakes (2.68) and in contrast, the respondents of the study carried out here do not care as much as them. Another difference can be observed in variable 18, the present study shows that students do not get nervous when the teacher asks questions, but Horwitz et al. claimed that those learners did get nervous in that kind of situation. Two similarities can be observed in both researches. All students claim that they do not mind to volunteer answers in class and they like their teacher to correct every single mistake. It is true that the non bilingual students of this research do not worry about making mistakes, but at the same time they want their teacher to correct them and know which linguistic form is the correct.

How the teacher's way of teaching influences the class

The purpose of this last section is to observe the different behaviours of teachers and how their attitudes could affect their students' behaviours. A 
table with eight items was designed and three teachers have been observed. As previously mentioned, the students observed in session 2 are the same students who completed the questionnaire. At the moment of designing Table 5, all the aspects which influence most on creating anxiety on learners were taken into consideration. All these teachers teach English as a second language at different stages: ESO and Bachillerato, although the three classes observed here only belong to Compulsory Secondary Education.

Having a look at table 5, it is very clear that teachers in the first and the third sessions fulfill all the items observed in a very positive way. In contrast, the second session shows how negative the teacher's attitude is with the students.

The teacher in session 1 makes every student participate. She makes them feel good and important in the process of acquiring their SL. Feelings of confidence are transmitted, such as "you are a machine!" and she gives confirmation to all what these students do. For instance, when learners are working on their own, this teacher checks their individual work. Although this group does not belong to the bilingual program, these students are willing to use English all the time and no pressure is put on them. The teacher said that it had been very hard to create this environment in the class, because students' relationships were not good enough at the beginning of the course. Therefore, it is more than clear that this teacher has made a great effort in her classes.

In session 2, a different situation takes place. This teacher encourages students to participate just $63 \%$ of the total time. She uses the attendance list to name them; therefore, students know when they are going to be called and in the waiting time, they do not pay attention at all. She makes fun of lower students and there is not an appropriate environment where students can work properly. Negative statements are very common, such as "I am bored" (student) and "you bore me" (teacher). "That is not logical" is an example of the type of confirmation that students receive when they are wrong. This teacher can cause and increase anxiety, since her intervention is mostly negative.

In session 3, both the teacher and students use English all the time in spite of not belonging to a bilingual class. Everybody has an opportunity to give an opinion or answer and there is a relationship of trust among them. The teacher sometimes makes jokes, so a good environment can be found. Some students do not pay attention all the time and the teacher makes his best to motivate them. 


\section{Conclusion}

The findings of this study show how there is a clear distinction between bilingual and non bilingual students. Both are interested in the subject and want English to be used all the time, but the difference comes with their marks and behaviour in the class. Maybe the fact that they study in the non bilingual program pressures them to behave in that way. There are clear signs of how these students have been divided in a very obvious manner in the school; being the non bilingual the "worst" students in relation to behaviour, attitudes, proficiency level at the language and marks.

At first sight, what we can expect from a bilingual group is not going to be the same to what we expect from non bilingual students. However, results in this research have shown that we must break away with all those mistaken beliefs. For instance, in spite of having a bad behaviour and attitude in the class, non bilingual students ask for quiet lessons or are worried about the consequences of failing English.

Results have also shown that bilingual students are the most confident when using their SL and they are highly motivated. However, they would feel embarrassed or nervous in some specific situations, while non bilingual students would not. Contrary to expectations, some bilingual learners suffer anxiety in several situations such as, having a conversation with native speakers.

Students from all the groups are able to identify all those aspects which fail or do not work in their classes. For instance, lack of motivation, participation, authentic English and lack of practice of productive and receptive skills, such as listening or speaking. All these students agree that a teacher must be patient, tactful, and respectful and treat all learners without any distinction. Based on this information, these are the aspects which could arise anxiety on students and if teachers bear them in mind, students would feel more comfortable in their SL classes.

In this study, girls and the bilingual group tend to like English more than boys and the rest of groups. All students who consider themselves as ordinary SL learners have more private tutoring at home than those students who think they are good or bad at English. This fact is a little bit shocking since there are many learners who are failing the subject, especially in group 2, and they are not receiving extra help. All the students who have a private tutor at home are those ones whose parents do not speak English. 
Two different types of teachers can be found in this research. On the one hand, there is an ideal teacher who increases her students' motivation and interest in their SL. Even though some learners do not like English so much, she makes a great effort to achieve it. Students are asked for opinions and they make decisions all together. By doing so, she creates a good relationship and environment in the class. On the other hand, there is a teacher who pressures students to get immediate answers. Therefore, learners do not have enough time to process their answers and it only makes them feel anxious or less motivated. Those students who need more help feel neglected and ignored by this teacher, since she asks only brighter students.

All teachers must take into account that they have the power to alter their students' attitude and motivation towards the foreign language and they must make them feel important in the process of acquiring their SL.

\section{Proposals for improvement}

As shown in results, bilingual students suffer anxiety in certain situations. With the purpose of facing these situations, many simple things can be done to put an end to the problem of anxiety in the language class. In order to meet with the third and last objective, some proposals and tools will be offered in this section.

As Rubio (2001) declares, teachers must change some students' thoughts which are not positive enough, so that learners have their minds in a positive state. Teachers should also be aware that even good learners can suffer mental blocks and they must pay attention to all students without making any distinction. They must be clear with the instructions they give, so students understand what they have to do in every single task (Rubio, 2002b). Teachers must show learners how important they are in the process of learning a SL, taking into account students' opinions when making decisions (García, 2011). As Zubko \& Ortega (2013) say "the classroom dynamic influences motivation to learn".

At least some affective activities should take place in every group of students. Introducing relaxing elements, such as songs, help to create an appropriate atmosphere where all students feel good (Silva, 2005 and Rubio, 2002c). Debates and pre-activities could be included before the main task takes place. By doing so, students would feel better since they have shared their opinions with other classmates and they feel more confident to speak up in front of others. Debates also help to talk about some possible problems 
related to anxiety in the language class (Crookall \& Oxford, 1991). For instance, learners could write down any problem they have and then, they could discuss it. As Arnaiz \& Pérez (2014) suggest "understanding students' sources of anxiety is an essential part of understanding how to intervene" ( $p$. 72). Group work helps students to increase their self-confidence. The use of topics of their interest increases helps to encourage learners and increases their motivation and attitude towards the subject. Enough time to think should be given to students (Ortega, 2002).

These strategies are as effective as the traditional techniques which other teachers use (Arnold, 2011). As it can be seen, it is not that difficult to help language students to feel relaxed during the whole lessons. A simple smile can help to make learners feel relaxed. By doing little things, a big change can be made in society.

\section{LFE About the author}

Alba Muñoz has received a degree in English Studies from the University of Granada in 2013 and a master degree in teaching Secondary Education, Upper Secondary Education, Professional Training and Languages. Her research interests include second language acquisition (SLA) and relationships among anxiety, attitude and motivation.

José Luis Ortega, PhD, is a principal lecturer at the University of Granada who has been in charge of International Relations at the Faculty of Education, Head of in-Service Training at the University of Granada. His research interests include motivation, classroom management, international teaching practice periods and bilingualism.

\section{LFE Article history}

Paper received: 19th February 2015

Paper received in revised form and accepted for publication: 6th March 2015 


\section{References}

Arnaiz, P. \& Guillén, F. (2013). Anxiety in Spanish EFL students in different university degree programs. Anales de Psicología, 29 (2), 335-344.

Arnaiz, P. \& Pérez-Luzardo, J. (2014). Anxiety in Spanish EFL university lessons:

causes, responsibility attribution and coping. Studia Anglica Posnaniensia, 49

Arnold, J. (2009). Affect in L2 learning and teaching. Estudios de lingüística inglesa aplicada, 9, 145-151.

Arnold, J. (2011). Attention to Affect in Language Learning. Anglistik. International Journal of English Studies, 22(1), 11-22.

Arnold, J. \& Brown, D.H. (2000). Mapa del Terreno. En Jane Arnold (Ed.), El Dominio Afectivo en el Aprendizaje de Idiomas. Madrid: CUP.

Crookall, D. \& Oxford, R. (1991). Dealing with anxiety: some practical activities for language learners and teacher trainees. In E. Horwitz, \& D. Young, (Eds.), Language Anxiety. From Theory and Research to Classroom Implications (pp. 141-150). Nueva Jersey: Prentice Hall.

Dörnyei, Z. (2006). Individual differences in second language acquisition. Association Internationale de Linguistique Appliquée Review, 19, 42-68.

Dörnyei, Z., \& Skehan, P. (2003). Individual differences in second language learning. In C. J. Doughty, \& M. H. Long (Eds.), The handbook of second language acquisition ( pp. 589-630). Oxford: Blackwell.

Ellis, R. (2004). Individual Differences in Second Language Learning. In A. Davies \& C. Elder (Eds.), The handbook of applied linguistics (525-551). Oxford: Blackwell.

García, G. (2011). La ansiedad ante el aprendizaje de una segunda lengua. Autodidacta, 5, 41-55.

Guillén, F., Pérez-Luzardo, J. \& Arnaiz, P. (2013). Relación entre motivación y optimismo disposicional en aprendices de inglés como lengua extranjera en un contexto universitario. Revista de Educación, Extraordinario, 104-128.

Horwitz, E. (2001). Language anxiety and achievement. Annual Review of Applied Linguistics, 21, 112-126.

Horwitz, E. K., Horwitz, M. B., \& Cope, J. (1986). Foreign language classroom anxiety. The Modern Language Journal, 70, 125-132.

Marcos-Llinas, M. (2007). Variables afectivas en la clase de lenguas extranjeras. Interlingüística, 17, 676-678.

Ortega, C. A. (2002). Learners' anxiety in the language classroom. In F. Molina, \& G. Luque,

(Eds.), Uso del inglés en el aula: Lengua, literatura y traducción (pp. 253- 257). Jaén: Universidad de Jaén.

Ortega-Martín. J.L. \& Villoria, J. (2004). Classroom research. In D. Madrid \& N. McLaren (eds.), 
TEFL in Primary Education (521-550). Granada: Universidad de Granada.

Rubio, F. D. (2001). El pensamiento en la clase de inglés: Fuente de poder o vulnerabilidad. Estudios de Lingüística Aplicada (ELIA), 2, 49-56.

Rubio, F. D. (2002a). Una forma de reducir la ansiedad en los exámenes orales de inglés como lengua extranjera: técnica de reevaluación positiva. Estudios de Lingüística Aplicada (ELIA), 3, 173-185.

Rubio, F. D. (2002b). Making oral test more human and less-anxiety generating. Humanising Language Teaching Magazine (HLT), 4. Available at http://www.hltmag.co.uk/jul02/sart3.htm

Rubio, F. D. (2002c). Relaxation exercises for foreign language learners. In Andrewes, S.

(Eds.), ELT 2001: Just think before you do it (pp. 95-98). Granada: Gráficas Alhambra.

Rubio, F. D. (2004). La Ansiedad en el Aprendizaje de Idiomas. Huelva: Universidad de Huelva.

Scovel, T. (2000). Learning New Languages: A Guide to Second Language Acquisition. Boston: Heinle \& Heinle.

Silva, R. M. (2005). La reducción de la ansiedad en el aprendizaje de una lengua extranjera en la enseñanza superior: el uso de canciones. Interlingüística, 16 (2), 1029-1039.

Sparks, R. \& Ganschow, L. (1993). Searching for the cognitive locus of foreign language learning difficulties: Linking first and second language learning. The Modern Language Journal, 77, 289-302.

Stern, H. H. (1983). Fundamental Concepts of Language Teaching. Oxford: Oxford University Press.

Stevick, E.W. (1980). Teaching Languages: A Way and Ways. Rowley, MA: Newbury House.

Tsui, A.B.M. (1996). Reticence and anxiety in second language learning. Voices From the Language Classroom, 2 (4), 145-167.

Young, D. J. (1999). Affect in foreign language and second language learning: A practical guide to creating a low-anxiety classroom atmosphere. San Francisco: McGraw-Hill.

Zheng, Y. (2008). Anxiety and second/foreign language learning revisited. Canadian Journal for New Scholars in Education (CJNSE), 1 (1), 1-12.

Zubko, T. N. \& Ortega M. J.L. (2013). Using emotional intelligence in secondary schools to improve academic achievement and social competence in a foreign language setting. The International Journal of Learner Diversity and Identities, 20 (1), 1-17. 


\section{Appendix A}

CUESTIONARIO: Variables afectivas en el aprendizaje de inglés

Sexo: $\quad$ chica $\quad \square$ chico Edad:

1. ¿Te gusta el inglés? $\square$ Sí $\square$ No

2. Tu nivel de interés en la asignatura es: $\square$ bajo $\square$ medio $\square$ alto

3. ¿Cambiarías algo de la asignatura?

4. ¿Cómo te consideras en inglés? $\square$ bueno $\square$ normal $\square$ malo

5. ¿Has repetido alguna vez? $\square$ Sí $\square$ No

6. ¿Qué nota obtuviste el trimestre pasado?

7. Tus padres saben inglés: $\square$ nada $\square$ poco mucho

8. ¿Te hablan en casa en inglés? $\square$ Sí $\square$ No

9. ¿Tienes clases particulares de inglés? $\square$ Sí $\square$ No

10. ¿Sigues alguna serie en inglés? ¿Sí $\square$ No ¿Cuál?

11. ¿Has estado algún verano en el extranjero para practicar inglés? $\square$ Sí $\square$ No ¿Dónde?

12. Si pudieras dar un consejo a los futuros docentes de inglés, ¿Qué les recomendarías con respecto a cómo tratar a los alumnos?

13. No nos referimos a tu profesor/a actual, ¿pero crees que los profesores presionan demasiado a los estudiantes para que den una respuesta rápida o correcta? $\square$ Sí $\square$ No

14. ¿Cuentas con unos segundos para dar la respuesta o rápidamente la da un compañero en tu lugar?

15. ¿Crees que los alumnos han perdido el respeto a los profesores? $\square$ Sí $\square$ No 


\begin{tabular}{|c|c|c|c|c|}
\hline & & & $\mathrm{cal}$ & \\
\hline ITEMS & 1 & 2 & 3 & \\
\hline 17. Me da igual cometer errores delante de mis compañeros. & & & & \\
\hline $\begin{array}{l}\text { 19. Durante la clase pienso en cosas que no tienen nada que ver con la } \\
\text { asignatura. }\end{array}$ & & & & \\
\hline 20. Me da vergüenza hablar en inglés delante de mis compañeros. & & & & \\
\hline 21. Me preocupa suspender esta asignatura. & & & & \\
\hline 22. En clase me pongo tan nervioso que se me olvidan cosas que ya sé. & & & & \\
\hline $\begin{array}{l}\text { 23. No entiendo por qué algunos compañeros se ponen nerviosos cuando } \\
\text { tienen que participar en inglés. }\end{array}$ & & & & \\
\hline $\begin{array}{l}\text { 24. Me da vergüenza ofrecerme como voluntario para hacer un ejercicio o } \\
\text { leer. }\end{array}$ & & & & \\
\hline 25. Me pondría nervioso si hablara con nativos. & & & & \\
\hline 26. Aunque esté bien preparado/a me siento inquieto en mi clase de inglés. & & & & \\
\hline $\begin{array}{l}\text { 27. No me gusta que mi profesor/a de inglés esté pendiente de corregir cada } \\
\text { error que pueda cometer. }\end{array}$ & & & & \\
\hline $\begin{array}{l}\text { 28. Suelo sentarme en las últimas filas para evitar que me nombren o } \\
\text { participar. }\end{array}$ & & & & \\
\hline 29. Creo que mis compañeros son mejores en inglés que yo. & & & & \\
\hline $\begin{array}{l}\text { 30. En clase de inglés estoy más nervioso o tenso que en el resto de } \\
\text { asignaturas o clases. }\end{array}$ & & & & \\
\hline $\begin{array}{l}\text { 31. Cuando hablo en inglés pienso que mis compañeros se pueden reír de } \\
\text { mis errores. }\end{array}$ & & & & \\
\hline 32. Me encantaría tener más clases de inglés. & & & & \\
\hline 33. En clase siempre participan "los mismos". & & & & \\
\hline o que el inglés no es lo mío y que jamás aprenderé a ha & & & & \\
\hline
\end{tabular}

